\title{
Etoricoxib in the Prevention of Rat Mammary Carcinogenesis
}

\author{
P. ORENDÁŠ, I. AHLERS, P. KUBATKA ${ }^{1}$, E. AHLERSOVÁ, B. BOJKOVÁ, \\ M. KASSAYOVÁ, L. FRIEDMANOVÁ, J. KISKOVÁ, I. DATELINKA, \\ M. STAROSTOVÁ \\ Department of Animal Physiology, Institute of Biological and Ecological Sciences, \\ Faculty of Science, P.J. Safárik University, Košice, Slovak Republic \\ ${ }^{1}$ Department of Pharmacology, Jessenius Faculty of Medicine, Comenius University, Martin, Slovak Republic \\ Received July 27, 2006 \\ Accepted October 2, 2007
}

\begin{abstract}
Orendáš P., I. Ahlers, P. Kubatka, E. Ahlersová, B. Bojková, M. Kassayová, L. Friedmanová, J. Kisková, I. Datelinka, M. Starostová: Etoricoxib in the Prevention of Rat Mammary Carcinogenesis. Acta Vet. Brno 2007, 76: 613-618.

Several experimental studies suggest that non-steroidal antiinflammatory drugs have chemopreventive effects in mammary carcinogenesis. In this study, tumour suppressive effects of a selective inhibitor of cyclooxygenase-2 (COX-2) etoricoxib in the prevention of N-methyl-Nnitrosourea (NMU)-induced mammary carcinogenesis in Sprague-Dawley rats were evaluated. Etoricoxib was administered in the diet, at two concentrations: 1) $0.01 \mathrm{mg} / \mathrm{g}$ (ETO $0.001 \%$ ) and 2) $0.025 \mathrm{mg} / \mathrm{g}$ (ETO $0.0025 \%$ ). Although the chemopreventive effects were not statistically significant, remarkable tumour suppressive effects with the concentration of ETO $0.0025 \%$ were recorded. The incidence decreased by $4.31 \%$ and tumour frequency per group decreased by $6.67 \%$ when compared to the control group. Latency (the period from carcinogen administration to the first tumour appearance) increased by $7.28 \%$ in dose-dependent manner. The results of our experiments point to dose-dependent tumour suppressive effects of a higher concentration of etoricoxib (ETO $0.0025 \%$ ) when compared to the control group. They suggest that higher etoricoxib concentrations may enhance its tumour suppressive effects.
\end{abstract}

Mammary carcinogenesis, prevention, rats, coxibs, NSAIDs

Mammary gland cancer presents a serious health issue worldwide. Chemoprevention is assumed to be an effective way to combat carcinogenesis. Non-steroidal anti-inflammatory drugs (NSAIDs) are important drugs suppressing manifestations of inflammation. They are frequently administered in the treatment of rheumatoid arthritis to alleviate pain and fever. Recently, their preventive effects in carcinogenesis were reported. Clinical studies aimed at long-term application of various NSAIDs reported a pronounced decline in the risk of colon (Thun et al. 1991), mammary gland (Harris et al. 1999), prostatic (Nelson and Harris 2000), and lung cancer (Harris et al. 2002). The experimental studies with laboratory animals proved chemopreventive effects of NSAIDs in various types of neoplasia, including mammary gland cancer.

Similarly, our group proved the chemopreventive effects of indomethacin administered in drinking water (Môciková-Kalická et al. 2001), nimesulide applied subcutaneously (Kubatka et al. 2002) and those of rofecoxib administered with the diet in mammary carcinogenesis in female rats (Kubatka et al. 2003).

The primary effect of NSAIDs is the suppression of prostanoid synthesis by inhibition of cyclooxygenase (COX) activity. Two isoforms of COX were identified: constitutive COX1 and inducible COX-2 isoform found predominantly under pathological conditions, e.g. inflammation and neoplasia.

Expression of COX-2 may influence the process of carcinogenesis via several mechanisms: peroxidase activity of COX-2 supports the conversion of procarcinogens to carcinogens (Fosslien 2000), inhibitory effect of prostaglandins in immune reactions was

\footnotetext{
Address for correspondence:

Prof. MUDr. Ivan Ahlers, DrSc.

Department of Animal Physiology

Institute of Biology and Ecology

Faculty of Science, P.J. Safárik University

Moyzesova 11, 04167 Košice, Slovak Republic
}

Phone: +421905 133775
Fax:+421556222 124
E-mail:iahlers@kosice.upjs.sk
http://www.vfu.cz/acta-vet/actavet.htm 
found (Rita and Young 1994), as well as angiogenetic (Tsujii 1998) and antiapoptotic effects (Fosslien 2000).

On the other hand, enhanced invasion of tumour cells with increased expression of COX-2 was observed. Brueggemeier et al. (1999) pointed to linear dependence between aromatase gene (CYP 19) expression and expression of COX-2 in mammary carcinoma. The above mentioned facts predetermine the use of NSAIDs in mammary carcinogenesis prevention.

From the pharmaco-dynamic point of view, inhibitors COX-1 (acetylsalicylic acid, indomethacin, ibuprofen) display serious side effects on the gastrointestinal tract associated with their long-term application. These undesirable effects are markedly reduced in administration of COX-2 inhibitors (nimesulide, meloxicam, coxibs), supporting their preference in long-term use. Etoricoxib represents new NSAID generation selectively inhibiting COX-2 activity in human cells in vitro with minimal COX-1 activity inhibition.

The present study was aimed at evaluation of chemopreventive effects of etoricoxib in mammary carcinogenesis in female Sprague-Dawley rats.

\section{Materials and Methods}

Female Sprague-Dawley rats obtained from Charles River Laboratories (Budapest, Hungary) aged 33 - 37 days, weighing $101-125 \mathrm{~g}$ were used in the experiment. The animals were adapted to standard vivarium conditions with the temperature of $23 \pm 2{ }^{\circ} \mathrm{C}$, relative humidity $60-70 \%$, artificial regimen light : dark $=12: 12 \mathrm{~h}$, with lights on from 7:00 h (light intensity 150 lux per cage, light source: fluorescent lamps Tesla - $40 \mathrm{~W}$ ). During the experiment, animals had access to tap water ad libitum. Etoricoxib (Merck Research Laboratories, Merck Frosst, Montreal, Canada) was administered in a chow ST-1 Bergman (Jeseničky u Prahy, Czech Republic). Etoricoxib was administered in the chow at two concentrations: $0.01 \mathrm{mg} / 1 \mathrm{~g}$ (ETO $0.001 \%$ or ETO10) and $0.025 \mathrm{mg} / 1 \mathrm{~g}$ (ETO $0.0025 \%$ or ETO25). Mammary carcinogenesis was induced by N-methyl-N-nitrosourea (NMU) (Sigma, Deisenhofen, Germany), administered at two intraperitoneal doses $(50 \mathrm{mg} / \mathrm{kg})$ in a 6-day interval between postnatal days 42 - 48. NMU was freshly prepared by dissolving in isotonic saline solution ( $0.5 \mathrm{ml}$ per animal).

Chemoprevention with etoricoxib began 7 days before carcinogen administration and lasted until the end of the experiment (20 weeks after NMU administration). Animals were divided into three experimental groups: 1) control group without chemoprevention; 2) chemoprevention with etoricoxib at a concentration of $0.001 \%$ (ETO $0.001 \%$ ); 3 ) chemoprevention with etoricoxib at a concentration of $0.0025 \%$ (ETO $0.0025 \%$ ). Each group consisted of 20 animals. The animals were weekly weighed and palpated in order to record the incidence, number, location and size of tumours. In the $21^{\text {st }}$ week of the experiment (dated from the first NMU application), the animals were sacrificed by quick decapitation. Mammary tumours were excised, weighed and tumour size was recorded. The following basic variables of mammary carcinogenesis were assessed in each group: 1) tumour incidence as the percentage representation of tumour-bearing animals

2) tumour frequency per group as the average number of tumours per group

3) tumour frequency per animal as average number of tumours per tumour-bearing animals

4) average tumour volume

5) latency period determined by the period from carcinogen administration to the appearance of the first tumour in an animal.

The effect of a chemopreventive agent on the body weight gain (evaluated from the initiation until the end of the experiment), food and water intake was observed. Food and water intake during $24 \mathrm{~h}$ was observed in the $6^{\text {th }}$, $11^{\text {th }}$ and $20^{\text {th }}$ week after carcinogen administration in 6 measurements (twice in a given week).

Tumour incidence was evaluated by Mann-Whitney U-test, other variables by one-way analysis of variance or Kruskal-Wallis test $(P<0.05$ level $)$. Tumour volumes were calculated according to formula V $\left(\mathrm{mm}^{3}\right)=\pi \times \mathrm{S}_{1}{ }^{2}$ $\mathrm{x}_{2} / 12$; where $\left(\mathrm{S}_{1}<\mathrm{S}_{2}\right), \mathrm{S}_{1}$ is tumour width and $\mathrm{S}_{2}$ tumour length, $\mathrm{S}_{1}$ and $\mathrm{S}_{2}$ were measured perpendicularly. The experiment was carried out from October 2005 to March 2006.

\section{Results}

Preventive effects of etoricoxib in female Sprague-Dawley rat mammary carcinogenesis are summarized in Table 1.

Etoricoxib administered at a lower dose in the experimental group ETO 10 did not significantly influence the observed indicators of mammary carcinogenesis (incidence, frequency, tumour volume, latency). In the experimental group ETO 25 the incidence 
slightly decreased by $4.31 \%$, tumour frequency per group by $6.67 \%$, frequency per animal by $2.44 \%$. The latency period was prolonged by 7 days. No macroscopic changes were observed in the selected organs (liver, kidneys, small intestine, stomach and lungs).

Table 1. Chemopreventive effects of etoricoxib in NMU-induced mammary carcinogenesis in female Sprague-Dawley rats in the final $21^{\text {st }}$ week of the experiment

\begin{tabular}{|l|c|c|c|}
\hline \multirow{2}{*}{ Group } & CONT & ETO 10 $(0.001 \%)$ & ETO 25 $(0.0025 \%)$ \\
\cline { 2 - 4 } & $\mathrm{n}=20$ & $\mathrm{n}=18$ & $\mathrm{n}=19$ \\
\hline Number of tumour bearing animals & 11 & 10 & 10 \\
\hline Tumour incidence* & $55.00 \pm 11.41$ & $55.56 \pm 12.05$ & $52.63 \pm 11.77$ \\
\hline Tumour frequency per group ** & $0.90 \pm 0.28$ & $1.39 \pm 0.41$ & $0.84 \pm 0.26$ \\
\hline Tumour frequency per animal** & $1.64 \pm 0.39$ & $2.50 \pm 0.50$ & $1.60 \pm 0.34$ \\
\hline Tumour volume $\left(\mathrm{mm}^{3}\right)^{* *}$ & $905.24 \pm 303.79$ & $1632.35 \pm 799.94$ & $1692.02 \pm 1025.64$ \\
\hline Tumour latency $(\text { days })^{* *}$ & $103.09 \pm 7.32$ & $111.30 \pm 7.70$ & $110.60 \pm 9.78$ \\
\hline Initial body weight $(\mathrm{g})$ & $120.25 \pm 1.83$ & $118.35 \pm 1.32$ & $118.40 \pm 1,68$ \\
\hline Body weight gain-final analysis $(\mathrm{g})$ & $72.25 \pm 4.71$ & $90.21 \pm 9.12$ & $71.04 \pm 5.80$ \\
\hline
\end{tabular}

*Data are expressed as means \pm SEM

**Data are expressed as means \pm SEM

Significantly different, ${ }^{\mathrm{s}} P<0.05$ vs. CONT

Daily food intake per rat in ETO 10 ranged between $19.95 \mathrm{~g}$ and $21.53 \mathrm{~g}$ and daily drug doses ranged between $0.629-0.885 \mu \mathrm{g}$ etoricoxib/g b.w. In group ETO 25 the daily food intake per rat was between 19.25 and $20.43 \mathrm{~g}$ and daily drug dose was between 1.66 and $2.19 \mu \mathrm{g}$ etoricoxib/g/b.w. The food intake revealed a significant difference in the $11^{\text {th }}$ week between groups ETO 10 and ETO 25 (10.47\% decrease in food intake in group ETO 25 as opposed to ETO 10) and in the $20^{\text {th }}$ week - between CONT and ETO $25(10.55 \%$ decrease in food intake in group ETO 25 in comparison to CONT) (Table 2).

Daily water intake per rat in the $6^{\text {th }}$ week ranged between $34.75 \mathrm{ml}$ and $37.5 \mathrm{ml}$, in the $11^{\text {th }}$ week between $35.25 \mathrm{ml}$ and $42.29 \mathrm{ml}$, in the $20^{\text {th }}$ week between $41.5 \mathrm{ml}$ and $47.09 \mathrm{ml}$. Significant difference in water intake was recorded in the $11^{\text {th }}$ week between groups CONT and ETO 25 (13.5\% decrease in water intake in group ETO 25 as opposed to CONT) and between ETO 10 and ETO 25 (7.94\% decrease in water intake in group ETO 25 as opposed to ETO 10) (Table 3).

Experimental groups

CONT - control group of animals with administered carcinogen without chemoprevention

ETO $10(0.001 \%)$ - animal group with administered carcinogen + chemoprevention by etoricoxib received in chow at a concentration of $0.01 \mathrm{mg} / \mathrm{g}$

ETO $25(0.0025 \%)$ - group with administered carcinogen + chemoprevention by etoricoxib received in chow at a concentration of $0.025 \mathrm{mg} / \mathrm{g}$

Table 2. Effects of etoricoxib on food intake

\begin{tabular}{|c|c|c|c|}
\hline \multirow{2}{*}{$\begin{array}{c}\text { Weeks after NMU administration } \\
6\end{array}$} & CONT & ETO 10 (0.001\%) & ETO 25 (0.0025\%) \\
\cline { 2 - 4 } & $20.43 \pm 0.45$ & $21.53 \pm 0.46$ & $20.30 \pm 0.54$ \\
\hline 11 & $20.73 \pm 1.50$ & $21.50 \pm 0.68$ & ${ }^{\mathrm{a}} 19.25 \pm 0.59(-10.47)$ \\
\hline 20 & $22.84 \pm 0.91$ & $19.95 \pm 2.97$ & ${ }^{\mathrm{b}} 20.43 \pm 0.68(-0.55)$ \\
\hline
\end{tabular}

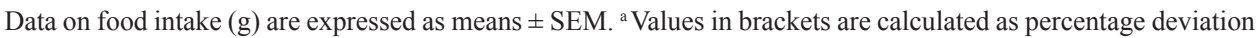
ETO 25 vs. ETO $10(100 \%)$. ${ }^{\mathrm{b}}$ Values in brackets are calculated as percentage deviation ETO 25 vs. CONT (100\%). Significantly different, ${ }^{\mathrm{a}, \mathrm{b}} \mathrm{P}<0.05$ vs. CONT. 
Table 3. Effects of etoricoxib on water intake

Data on water intake $(\mathrm{ml})$ are expressed as means $\pm \mathrm{SEM}$.

\begin{tabular}{|c|c|c|c|}
\hline Weeks after NMU administration & CONT & ETO 10 (0.001\%) & ETO 25 (0.0025\%) \\
\hline 6 & $34.75 \pm 1.42$ & $37.50 \pm 2.07$ & $35.50 \pm 2.62$ \\
\hline 11 & $40.75 \pm 1.59$ & $42.29 \pm 2.47$ & $\begin{array}{c}35.25 \pm 1.35 \\
\text { a }(-13.50),{ }^{\mathrm{b}}(-7.94)\end{array}$ \\
\hline 20 & $45.08 \pm 3.72$ & $47.09 \pm 3.10$ & $41.5 \pm 1.87$ \\
\hline
\end{tabular}

a Values in brackets are calculated as percentage deviation ETO 25 vs. CONT (100\%). Significantly different, ${ }^{\text {a }} P<0.05$ vs. CONT.

${ }^{\mathrm{b}}$ Values in brackets are calculated as percentage deviation ETO 25 vs. ETO 10 (100\%). Significantly different, ${ }^{\mathrm{b}} P<0.05$ vs. ETO 10 .

\section{Discussion}

Etoricoxib (Arcoxia, Merck Sharp and Dohme, 60, 90, and $120 \mathrm{mg}$ tbl) is a new generation of highly selective coxibs, inhibitors of COX-2 activity, indicated for the treatment of osteoarthritis, rheumatoid arthritis, ankylosing spondylitis, or gout arthritis. At present, medical practice prefers NSAIDs with predominant inhibition of COX-1 (mostly ibuprofen and diclofenac), with predominant COX-2 inhibition (nimesulide) and selective COX-2 inhibition: coxibs (celecoxib, rofecoxib, parecoxib, etoricoxib, lumiracoxib, valdecoxib). Coxibs are assumed to be administered in the long-term treatment of patients suffering from arthritis due to lower incidence of gastrointestinal side effects. Several recent studies pointed to an increased incidence of thromboembolic events associated with the use of coxibs (Howard et al. 2004; Kearney et al. 2006). Increased incidence of vascular events was reported for ibuprofen and diclofenac, too. Rofecoxib and celecoxib were associated with increased incidence of myocardial infarction chiefly attributable to higher-dose daily drug intake (Kearney et al. 2006). In fact, certain coxibs were withdrawn from the market and the reasons of cardiovascular complications attributed to the therapy remain unclear. Targeted prospective trials as well as new generations of the above cited drugs more concerned to their cardiovascular safety may find the answers to the discussed issues.

Antineoplastic effect after long-term NSAIDs administration is proved to be beneficial. The preventive effects of those substances were ascribed to pleiotropy of their mechanisms of action including antiinflammatory, immunostimulating, antiproliferative, antiangiogenic and proapoptotic effects. Regular long-term use of certain NSAIDs markedly reduced the incidence of colon, lung, breast, prostate, and gastrointestinal carcinoma (Anderson 2002; Harris et al. 2005). Significant risk reductions were observed after five or more years of ibuprofen and Aspirin use (100 g and more daily, sufficient data analysis of 91 epidemiological studies) for 7 - 10 malignancies, of these $63 \%$ for colorectal cancer, $62 \%$ for gastric and $47 \%$ for ovarian cancer. The efficacy of NSAID was dose-dependent and stronger with longer duration of use (Harris et al. 2005). Hull (2005) emphasized that it is not sufficient to associate coxib effectiveness only with a reduced risk of gastrointestinal complications but also with a direct relation to $\mathrm{COX}-2$ expression in tumours. COX-2 expression leads to enhanced susceptibility of DNA to mutagenesis, increased angiogenesis, increased carcinogen activation mainly through peroxidases, responsibility in cell immunity shifts from $\mathrm{Th}_{1}$ to $\mathrm{Th}_{2}$ lymphocytes; resistance to apoptosis increases and invasiveness of transformed cells is promoted (Hull 2005). Retrospective epidemiological studies pointed to a reduced risk score of breast cancer in celecoxib and rofecoxib users (Harris et al. 2006).

Animal studies play an important role in the evaluation of the effects of NSAIDs in oncochemopreventive projects. Our group proved the efficacy of indomethacin (Môciková-Kalická e al. 2001) and nimesulide (Kubatka et al. 2002) in the prevention 
of experimental mammary carcinogenesis in female Sprague-Dawley rats. The group of R.E. Harris repeatedly confirmed preventive effects of celecoxib in female rat mammary carcinogenesis (Harris et al. 2000; Alshafie et al. 2000; Abou-Issa et al. 2001). We observed a clear dose-dependent rofecoxib action resulting in decreased mammary tumour incidence, frequency and volume in female Sprague-Dawley rats (Kubatka et al. 2003).

Our new findings are the first report on possible preventive effects of etoricoxib in experimental mammary carcinogenesis. The results indicate some influence on carcinogenesis associated with a higher daily dose of coxib. It may be assumed that the dose was insufficient and lowered by decreased food (and water) intake in these experimental animals between the $11^{\text {th }}$ and $20^{\text {th }}$ weeks. The issue of dosage may play a vital role in further concerns about possible prevention of tumorigenesis with long-term administration of NSAIDs. Alternative modes of construction and use of new NSAIDs (e.g. NO-containing drugs) will be searched in the future, for ways to prevent imbalance in blocked synthesis of prostaglandin, thromboxan, prostacycline and other substances production. The effort to attain highly selective COX-systems is likely to be supported by reduction of undesirable side effects mainly in cardiovascular events.

\section{Etorikoxib v prevencii mamárnej karcinogenézy potkanov}

Viaceré experimentálne štúdie poukazujú na chemopreventívny účinok nesteroidných antiflogistík u mamárnej karcinogenézy. V tomto experimente sme sledovali tumorsupresívny účinok selektívneho inhibítora cyklooxygenázy-2 (COX-2) etorikoxibu v prevencii mamárnej karcinogenézy u potkanov kmeňa Sprague-Dawley, ktorá bola indukovaná N-metyl-N-nitrózoureou (NMU). Etorikoxib bol podávaný v dvoch odlišných dávkach: 1. s koncentráciou $0,01 \mathrm{mg} / \mathrm{g}$ potravy (ETO 0,001\%) a 2 . s koncentráciou $0,025 \mathrm{mg} / \mathrm{g}$ potravy (ETO 0,0025\%). Aj ked' chemopreventívny účinok nebol pri štatistickom hodnotení preukázaný, predsa bol zaznamenaný určitý tumorsupresívny efekt pri koncentrácii ETO $0,0025 \%$. Tu sme zistili aj pokles incidencie o 4,31\% a pokles frekvencie nádorov na skupinu o 6,67 \% v porovnaní s kontrolnou skupinou. Latencia (doba od podania karcinogénu do objavenia sa prvého nádoru) vzrástla u vyššej dávky o 7,28 \%. Výsledky našich experimentov poukazujú na určitý tumorsupresívny efekt vyššej dávky etorikoxibu ETO 25 (ETO 0,0025 \%) oproti kontrole čo môže naznačovat', že s vyššou koncentráciou podaného etorikoxibu narastá aj jeho tumorsupresívny účinok.

\section{Acknowledgement}

We wish to thank Merck Research Laboratories (Merck Frosst, Montreal, Canada) for the generous gift of etoricoxib (Arcoxia).

The project 1/2355/05 was supported by the Grant Science Agency-VEGA, Ministry of Education, Slovak Republic. Experiment was approved by the State Veterinary and Food Administration of Slovak Republic by accreditation No. Ro-930/05-221/C.

\section{References}

ABOU-ISSA HM, ALSHAFIE GA, SEIBERT K, KOKI AT, MASFERRER JL, HARRIS RE 2001: Doseresponse effects of the COX-2 inhibitor, celecoxib, on the chemoprevention of mammary carcinogenesis. Anticancer Res 21: 3425-3432

ALSHAFIE GA, ABOU-ISSA HM, SEIBERT K, HARRIS RE 2000: Chemotherapeutic evaluation of celecoxib, a cyclooxygenase-2 inhibitor, in a rat mammary tumor model. Oncol Rep 7: 1377-1381

ANDERSON WA, UMAR A, VINER JL, HAWK ET 2002: The role of cyclooxygenase inhibitors in cancer prevention. Curr Pharm Des 8: 1035-1062

BRUEGGEMEIER RW, QUINN AL, PARRETT ML, JOARDER FS, HARRIS RE, ROBERTSON FM 1999: Correlation of aromatase and cyclooxygenase gene expression in human breast cancer specimens. Cancer Lett 140: $27-35$

FOSSLIEN E 2000: Molecular pathology of cyclooxygenase-2 in neoplasia. Ann Clin Lab Sci 30: 3-21

HARRIS RE, ALSHAFIE GA, ABOU-ISSA H, SEIBERT K 2000: Chemoprevention of breast cancer in rats by celecoxib, a cyclooxygenase 2 inhibitor. Cancer Res 60: 2101-2103 
HARRIS RE, BEEBE-DONK J, ALSHAFIE G 2006: Reduction in the risk of human breast cancer by selective cyclooxygenase-2 (COX-2) inhibitors. BMC cancer 6: 27

HARRIS RE, BEEBE-DONK J, DOSS H, BURR DOSS D 2005: Aspirin, ibuprofen, and other non-steroidal anti-inflammatory drugs in cancer prevention: A critical review of non-selective COX-2 blockade. Oncol Rep 13: $559-583$

HARRIS RE, BEEBE-DONK J, NAMBOODIRI KK 2001: Inverse association of non-steroidal anti-inflammatory drugs and malignant melanoma among women. Oncol Rep 8: 655-657

HARRIS RE, BEEBE-DONK J, SCHULLER HM 2002: Chemoprevention of lung cancer by non-steroidal antiinflammatory drugs among cigarette smokers. Oncol Rep 9: 693-695

HARRIS RE, KASBARI S, FARRAR WB 1999: Prospective study of nonsteroidal anti-inflammatory drugs and breast cancer. Oncol Rep 6: 71-73

HOWARD PA, DELAFONTAINE P 2004: Nonsteroidal anti-inflammatory drugs and cardiovascular risk. J Am Coll Cardiol 43: 519-525

HULL MA 2005: Cyclooxygenase-2: How good is it as a target for cancer chemoprevention? Eur J Cancer 41: 1854-1863

KEARNEY PM, BAIGENT C, GODWIN J, HALLS H, EMBERSON JR, PATRONO C 2006: Do selective cyclo-oxygenase-2 inhibitors and traditional non-steroidal anti-inflammatory drugs increase the risk of atherothrombosis? Meta-analysis of randomised trials. Brit Med J 332: 1302-1308

KUBATKA P, KALICKÁ K, CHAMILOVÁ M, AHLERSOVÁ E, AHLERS I, BOJKOVÁ B, ADÁMEKOVÁ E 2002: Nimesulide and melatonin in mammary carcinogenesis prevention in female Sprague-Dawley rats. Neoplasma 49: 255-259

KUBATKA P, AHLERS I, AHLERSOVÁ E, ADÁMEKOVÁ E, LUK P, BOJKOVÁ B, MARKOVÁ M 2003: Chemoprevention of mammary carcinogenesis in female rats by rofecoxib. Cancer Lett 202: 131-136

MÔCIKOVÁ-KALICKÁ K, BOJKOVÁ B, ADÁMEKOVÁ E, MNÍCHOVÁ-CHAMILOVÁ M, KUBATKA P, AHLERSOVÁ E, AHLERS I 2001: Preventive effect of indomethacin and melatonin on 7,12-dimethylbenz (a)anthracene-induced mammary carcinogenesis in female Sprague-Dawley rats. A preliminary report. Folia Biol Prague 47: 75-79

NELSON JE, HARRIS RE 2000: Inverse association of prostate cancor and non-steroidal anti-inflammatory drugs (NSAIDs): results of a case-control study. Oncol Rep 7: 169-170

RITA M, YOUNG I 1994: Eicosanoids and the immunology of cancer. Cancer Met Rev 13: 337-348

THUN MJ, NAMBOODIRI MM, HEATH CWJ 1991: Aspirin use and reduced risk of fatal colon cancer. N Engl J Med 325: 1593-1596

TSUJII M, KAWANO S, TSUJI S, SAWAOKA H, HORI M, DUBOIS RN 1998: Cyclooxygenase regulates angiogenesis induced by colon cancer cells. Cell 93: 705-716 